\title{
The Diagenetic Alteration of the Carbonate Rocks from the Permian Qixia Formation as Response to Two Periods of Hydrothermal Fluids Charging in the Central Uplift of Sichuan Basin, SW China
}

\author{
Pei Chen ${ }^{1}$, Meiyan Fu ${ }^{1,2, *}$, Hucheng Deng ${ }^{1,2}$, Wang $\mathrm{Xu}^{1,2}$, Dong $\mathrm{Wu}^{1,2}$, Puwei He ${ }^{3}$ and Hengwei Guo ${ }^{1}$ \\ 1 College of Energy, Chengdu University of Technology, Chengdu 610059, China; \\ jackychen@stu.cdut.edu.cn (P.C.); denghucheng@cdut.cn (H.D.); xuwang19@cdut.edu.cn (W.X.); \\ wudong19@cdut.edu.cn (D.W.); lg0111@stu.cdut.edu.cn (H.G.) \\ 2 State Key Laboratory of Oil and Gas Reservoir Geology and Exploitation, Chengdu University of Technology, \\ Chengdu 610059, China \\ 3 PetroChina Southwest oil \& Gasfield Company, Chengdu 646000, China; hebowei@petrochina.com.cn \\ * Correspondence: fumeiyan08@cdut.cn; Tel.: +86-185-0283-0103
}

check for updates

Citation: Chen, P.; Fu, M.; Deng, H.; Xu, W.; Wu, D.; He, P.; Guo, H. The Diagenetic Alteration of the Carbonate Rocks from the Permian Qixia Formation as Response to Two Periods of Hydrothermal Fluids Charging in the Central Uplift of Sichuan Basin, SW China. Minerals 2021, 11, 1212. https://doi.org/ $10.3390 / \min 11111212$

Academic Editors: Katarzyna Jarmołowicz-Szulc, Leszek Marynowski and Peter Modreski

Received: 13 September 2021 Accepted: 26 October 2021 Published: 29 October 2021

Publisher's Note: MDPI stays neutral with regard to jurisdictional claims in published maps and institutional affiliations.

Copyright: (c) 2021 by the authors. Licensee MDPI, Basel, Switzerland. This article is an open access article distributed under the terms and conditions of the Creative Commons Attribution (CC BY) license (https:// creativecommons.org/licenses/by/ $4.0 /)$.

\begin{abstract}
The hydrothermal fluid-carbonate rock reaction is frequently regarded to occur in deepburial diagenesis, and the hydrothermal dissolution is usually distributed and takes place along the faults. Previous studies have suggested that there was hydrothermal fluid activity locally in the Permian Qixia Formation in Sichuan Basin, likely related to the Emeishan basalt eruption. However, the effect of hydrothermal fluids on the carbonate rocks of the Qixia Formation in the central uplift of Sichuan Basin is still unclear. Based on the characteristics and geochemical parameters of the diagenetic minerals, this study aims to reveal the diagenetic alteration related to the hydrothermal fluid-rock reaction in the Qixia Formation and reestablish the diagenetic evolution by using the timing of diagenetic mineral precipitation. The methods include petrographic observation; trace and rare earth element (REE) analysis; $\mathrm{C}, \mathrm{O}$ and $\mathrm{Sr}$ isotope measurement; fluid inclusion temperature measurement and cathodoluminescence analysis. According to the petrographic characteristics, the dolostones are mainly of crystalline structure, namely fine-medium crystalline dolostone, mesocoarse crystalline dolostone, and coarse crystalline dolostone, with the cathodoluminescence color becoming brighter in that order. The limestones from the Qixia Formation are of the bioclastic limestone type, with no cathodoluminescence color. Compared with dolostones, limestones have higher Sr content, lower Mn content, and heavier oxygen isotopes. With the crystalline size of dolostone becoming coarser, the oxygen isotopes of dolostones tend to become lighter. The mesocoarse crystalline dolostone has the highest Mn content and negative carbon isotope. Both limestones and dolostones have an obvious positive Eu anomaly in the Qixia Formation. However, the REE patterns of fine-medium crystalline dolostones are very different from those of meso-coarse crystalline dolostones. It is credible that there were two periods of hydrothermal fluid charging, with different chemical compositions. The first period of hydrothermal fluids could laterally migrate along the sequence boundary. Fine-medium crystalline dolostones were almost completely distributed below the sequence boundary and were dolomitized during the shallow burial period. As products of the hydrothermal fluid-dolostone reaction, the saddle-shaped dolomites in the meso-coarse crystalline dolostones were the evidence of the second period of hydrothermal fluids. As a result, the dolomitization model was established according to the timing of diagenetic mineral precipitation, which can improve that the geological understanding of the effect of hydrothermal fluid activities on the carbonate rocks in the Qixia Formation.
\end{abstract}

Keywords: Sichuan Basin; Permian; elements; isotope; dolostones; hydrothermal dolomitization 


\section{Introduction}

The genesis of dolostone is always the focus of carbonate reservoir research. Dolostone reservoirs are widely distributed in the Permian Qixia Formation of the paleo-uplift in the central Sichuan Basin, China. Formation of the dolostone in the Maokou Formation overlying the Qixia Formation in the central Sichuan Basin was thought to relate to hydrothermal activity, as evidenced by abnormally high fluid inclusion homogenization temperature, positive Eu anomaly, abnormal isotope of limestone, and saddle-shaped dolomites [1-3]. Hydrothermal dolomitization in the Permian period was mainly affected by the activity of the Emei mantle plume, induced by magma eruption at about $259 \mathrm{Ma}$ [4]. As a result, the dolomitization occurred with the hydrothermal fluid charging at this period [5-8]. However, previous studies were mostly concentrated on the northwest areas of Sichuan Basin, the relationship between the formation of dolostone and hydrothermal activity of the Qixia Formation in the central uplift of Sichuan Basin is still unclear.

Recently, the great exploitation potential of the Permian natural gas in Sichuan Basin has been shown. By the end of 2017, the accumulative proved reserves of natural gas in the Middle Permian in Sichuan Basin reached $881 \times 10^{8} \mathrm{~m}^{3}$ [9]. The Middle Permian Qixia Formation experienced early diagenesis during the most intensive basalt eruption [10]. The influence of the hydrothermal activities on the dolostone in the early diagenetic stage has not been well known. Based on the observation of thin sections; scanning electron microscopy (SEM) and energy dispersive spectroscopy (EDS) analysis; C, O, $\mathrm{Sr}$ isotopes measurement; cathode luminescence; and fluid inclusion homogenization temperature detection, this study aims to reveal the influence of hydrothermal activities on the formation and evolution of the dolostones in the Qixia Formation in the central uplift of the Sichuan Basin.

\section{Geological Setting}

The study area is located in the flank of the giant nose-shaped structure of LeshanLongnusi paleo-uplift (Figure 1b). The tectonic evolution in the study area was mainly affected by the central uplift of the Sichuan Basin [11,12]. The central uplift developed in the Caledonian period and finally formed in the Early Permian after multiple tectonic movements [13-16]. During the Middle Permian period, the uplift of the basin basement resulted in differential denudation at the top of the Middle Permian in the study area [17] (Figure 1c). Due to the Emei ground fissuring movement, a large amount of basalt erupted in the early stage of the Late Permian, with the basement fault's reactivation and hydrothermal fluid activity $[9,17,18]$. There are four stages of the Emei mantle plume activities [17]. In the first stage of the Emei, basalt began to erupt and the relative sea level fall occurred in the late Qixia period. The second stage was characterized by the extensional rifting from the early restricted platform to the basin facies in the middle and late Maokou period. In the third stage, the pervasive karstification with the significant fall of relative sea level, occurred in the end of the Maokou period. In the fourth stage of the basalt eruption, faults were activated, and hydrothermal fluid charged into reservoirs in the early period of the Late Permian [17].

In the study area, the strata from the Sinian to the Jurassic periods could be identified, while the Devonian is generally absent. The Ordovician to Carboniferous sediments can be found occasionally at the edge of the study area. As a result, the Permian strata directly overlaid the Cambrian one in most area. The Upper Permian strata is composed of the Longtan and the Changxing formations, and the Middle Permian could be divided into the Qixia Formation and the Maokou Formation. The Lower Permian consists of the Liangshan Formation [18-21]. The Qixia Formation has a conformable contact relationship with the Lower Permian Liangshan Formation and the Maokou Formation [21-23]. However, the parallel unconformity between the Qixia Formation and the Maokou Formation could be observed in the northwest Sichuan Basin [24,25].

During the Middle Permian, the Qixia Formation deposited on the shallow open marine setting, including shoal and back-shoal [26]. The Qixia Formation has a thickness 
of $80-110 \mathrm{~m}$ and can be divided into two members, e.g., the first member and the second member of the Qixia Formation. The first member of the Qixia Formation (Q1 Member) can be divided into two lithologic sections. The lower part of the Q1 Member is composed of the micritic limestones deposited in the deep marine, and the upper part consists of the bioclastic limestones and dolostones deposited on the shoals. The second member of the Qixia Formation (Q2 Member) mainly consists of bioclastic limestones, microsparry pelletoidal limestones, sparry intraclastic limestones, dolomitic limestones, and crystalline dolostones, with a small amount of marlstones. The skeletal grains in bioclastic limestones include foraminifera, algae, sponges, and bivalves $[19,22]$.

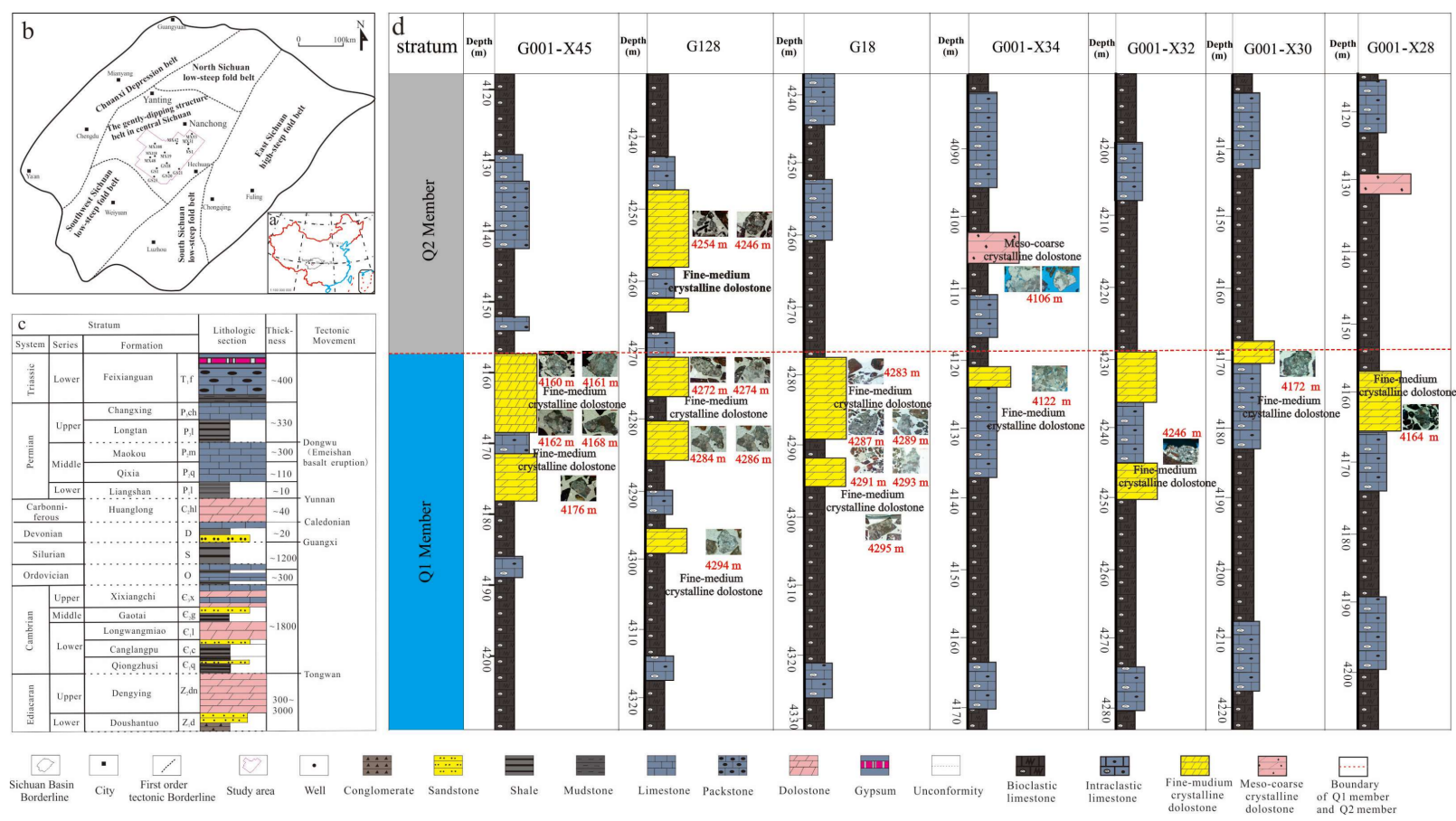

Figure 1. Geological setting of the study area. (a) The location of Sichuan Basin in southwestern China. (b) The study area is located in the red frame of (b). (c) Stratigraphic column and tectonic movements. (d) Vertical distribution of two types of dolostones.

\section{Methods}

The geological information of the Qixia Formation in this study covers 3 drilling wells with cores and 15 drilling wells with rock debris. The samples for petrographic observation and geochemical measurement were collected from two wells, MX108 (13 samples) from a depth between 4657.5 and $4690.78 \mathrm{~m}$ and MX42 (7 samples) from a depth between 4649.3 and $4655.62 \mathrm{~m}$. Overall, 17 samples were studied by means of cathode luminescence, one sample was observed by a scanning electron microscope, 15 samples were tested for the composition of rare earth elements, 13 samples were measured for the composition of microelements, 13 samples were tested for the composition of light isotopes and $\mathrm{Sr}$ isotope, 10 samples were measured for the fluid inclusion within dolomites and calcite cements, 7 samples were subjected to X-ray diffraction. These experiments were performed in the State Key Laboratory of Oil and Gas Reservoir Geology and Exploitation in the Chengdu University of Technology, China.

Petrographic investigation of thin sections was performed on a microscope (Leica 4500p, Wetzlar, Germany). Blue epoxy resin was used for casting, and alizarin red was used for dyeing. The cathode luminescence of dolostones was observed by the CL8200 MK5-2 (made in Britain) cold cathode instrument. The working voltage was $14 \mathrm{~kW}$, the current was $380 \mu \mathrm{A}$, and the vacuum degree was 0.003 mbar. Exposure time was adjusted to $12 \mathrm{~s}$. The scanning electron microscope instruments were a Quanta $250 \mathrm{FEG}+$ Inca 
X-max20 (FEI Company, Hillsboro, OR, USA) and an INCA x-max20 (Energy Disperse Spectroscopy, Oxford Instruments, High Wycombe, UK). The samples were coated with gold, and the electron images were taken with an acceleration voltage of $20 \mathrm{kV}$, a filament current of $240 \mu \mathrm{A}$, and a beam diameter of $4 \mu \mathrm{m}$.

The composition of elements was analyzed, using ICP-MS (inductively coupled plasma mass spectrometer, Agilent 7900, Santa Clara, CA, USA), with a test temperature of $20{ }^{\circ} \mathrm{C}$ and a relative humidity of $30 \%$. Before testing, the samples were sliced and ground into a 200 mesh.

Carbon and oxygen stable isotopes were measured by the mass spectrometer (MAT253plus, Hillsboro, OR, USA), with an analysis error of $\pm 0.1 \%$. Samples were processed through phosphoric acid method. The sample was dissolved with anhydrous phosphoric acid at $25^{\circ} \mathrm{C}$ for $24 \mathrm{~h}$. The $\delta$ values of $\mathrm{C}$ and $\mathrm{O}$ were reported relative to the V-PDB standard. The $Z$ value was calculated using the formula: $Z=2.048\left(\delta^{13} C+50\right)+0.498\left(\delta^{18} O+50\right)[27-29]$.

Sr isotope was determined by a multi-receiving inductively coupled plasma mass spectrometer (Neptune Plus, Waltham, MA, USA). The error of strontium isotope measurement was represented by $2 \sigma \pm$.

For the measurement of fluid inclusions, dolomites were selected. The homogenization temperature of fluid inclusions was measured on a THMS600 Cooling-Heating Stage (Linkam Scientific, Epsom, UK). The rate of temperature increase can be controlled to within $1{ }^{\circ} \mathrm{C} / \mathrm{min}$ when approaching the critical point.

The order degrees of dolomite were determined by $\mathrm{X}$-ray diffraction (XRD) using a Rigaku DMAX-3C equipped with $\mathrm{Cu} \mathrm{K} \alpha$ radiation $(40 \mathrm{kV}, 20 \mathrm{~mA})$. The order degrees of dolomite were calculated by the ratio of two diffraction peaks $\mathrm{d}(015) / \mathrm{d}(110)$.

\section{Results}

\subsection{Lithology}

The lithologies of the Qixia Formation in the study area are mainly composed of dolostone, dolomitic limestone, and limestone. According to the classification of dolomites [30], the dolostones are composed of fine-medium crystalline dolostones and meso-coarse crystalline dolostones.

\subsubsection{Fine-Medium Crystalline Dolostone}

The crystal morphology of most fine-medium crystalline dolostones is subhedral. The crystal size of dolostone was mostly between 0.10 and $0.40 \mathrm{~mm}$, and there was a mosaic contact relationship between crystals. The color of these dolostones under cathode luminescence was dark red (Figure 2a). The order degrees of fine-medium crystalline dolomites were from 0.69 to 0.79 , with an average of 0.75 . The cell parameters of these dolomites were different from that of the ideal dolomites. Suspected asphalt or heavy oil could be seen in the fine-medium crystalline dolostones under SEM (Figure 3). Energy spectrum analysis showed that the carbon content was as high as $80.3 \%$ (Table 1), which was identified as organic matter. Barite $\left(\mathrm{BaSO}_{4}\right)$ was also observed in the dolostone under SEM, identified by EDS. Through observation of a thin section, it was found that there were few visible pores in the fine-medium crystalline dolostone. The pores within the dolostone were mostly intercrystalline pores. These dolostones were prone to be distributed along the sequence boundary in the study area.

\subsubsection{Meso-Coarse Crystalline Dolostone}

Through core observation, the meso-coarse crystalline dolostones were found to be light gray to gray. The crystal sizes of meso-coarse crystalline dolostones ranged from 0.40 to $1.00 \mathrm{~mm}$. The crystals of these dolostones were almost euhedral, with a straight edge. In some cases, the cloudy core and bright rim of dolomites could be observed. The order degrees of meso-coarse crystalline dolomites were higher than that of fine-medium crystalline dolomites, ranging from 0.82 to 0.93 , with an average value of 0.87 (Table 2). The cell parameters of these dolomites were close to that of the ideal dolomite. The 
color of these dolostones under cathode luminescence was orange (Figure $2 b, d$ ). The caves, dissolved pores, and dissolved fractures developed on the cores of the meso-coarse crystalline dolostones. The caves are usually filled with saddle-shaped dolomites, calcites and asphalts. The saddle-shaped dolomites were identified by sickle, curved crystal face, and wave extinction under the cross-polarized light (Figure 2E,e). The distribution of meso-coarse crystalline dolostones was massive and scattered in the Q1 and Q2 members.
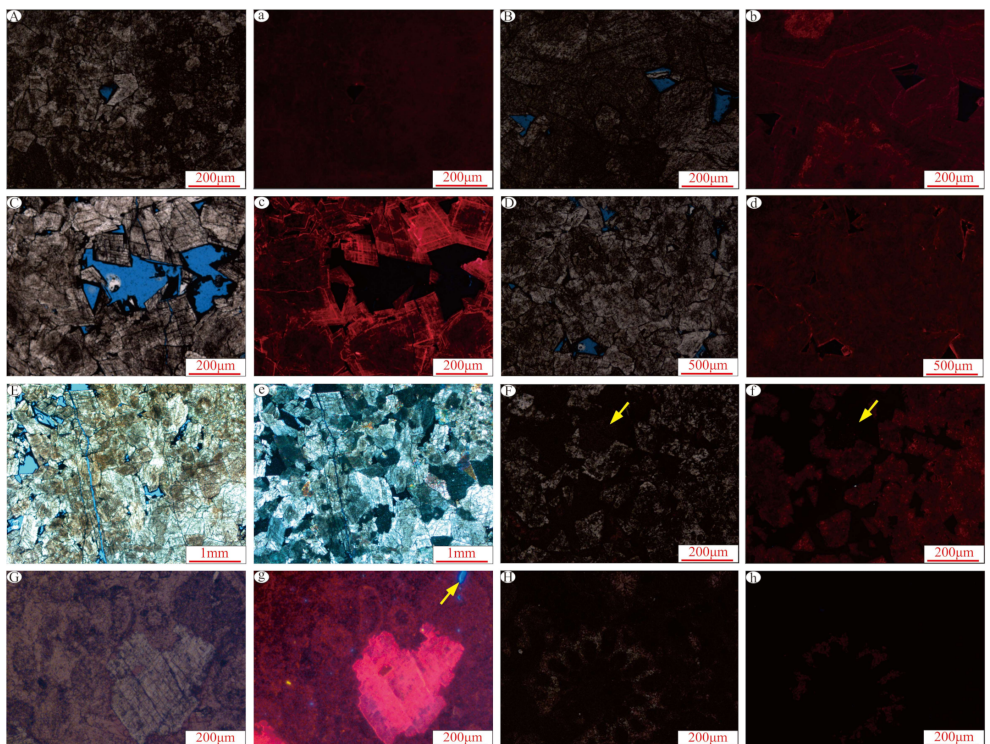

Figure 2. The thin-section image and CL color of the carbonate rocks from the Qixia Formation. (A) MX42, $4659.68 \mathrm{~m}$, fine-crystalline dolostone(-), (a) MX42, $4659.68 \mathrm{~m}$, fine-crystalline dolostone, the color is dark red under cathode luminescence; (B) MX42, $4655.62 \mathrm{~m}$, meso-coarse crystalline dolostone(-), (b) MX42, $4655.62 \mathrm{~m}$, meso-coarse crystalline dolostone, the color is deep red under cathode luminescence; (C) MX108, 4671.8 m, fine-medium crystalline dolostone(-), (c) MX108, $4671.8 \mathrm{~m}$, fine-medium crystalline dolostone, the color is red under cathode luminescence; (D) MX108, $4690.78 \mathrm{~m}$, meso-coarse crystalline dolostone(-), (d) MX108, $4690.78 \mathrm{~m}$, meso-coarse crystalline dolostone, the color is dark red under cathode luminescence; (E) MX108, $4690.78 \mathrm{~m}$, meso-coarse crystalline dolostone, with some saddle-shaped dolomites(-), (e) MX108, 4690.78 m, meso-coarse crystalline dolostone, with some saddle-shaped dolomites(+); (F) MX42, $4652.18 \mathrm{~m}$, dolomitic limestone(-), (f) MX42, $4652.18 \mathrm{~m}$, dolomitic limestone, the color of the limestone part under cathode luminescence is null; (G) MX42, $4649.30 \mathrm{~m}$, dolomitic limestone, fluorite(-), (g) MX42, $4649.30 \mathrm{~m}$, dolomitic limestone, the color of the dolomites part under cathode luminescence is red. The arrow indicates fluorite; (H) MX42, $4659.10 \mathrm{~m}$, bioclastic limestone(-), (h) MX42, $4659.10 \mathrm{~m}$, the bioclastic limestone parts are dark under cathode luminescence.
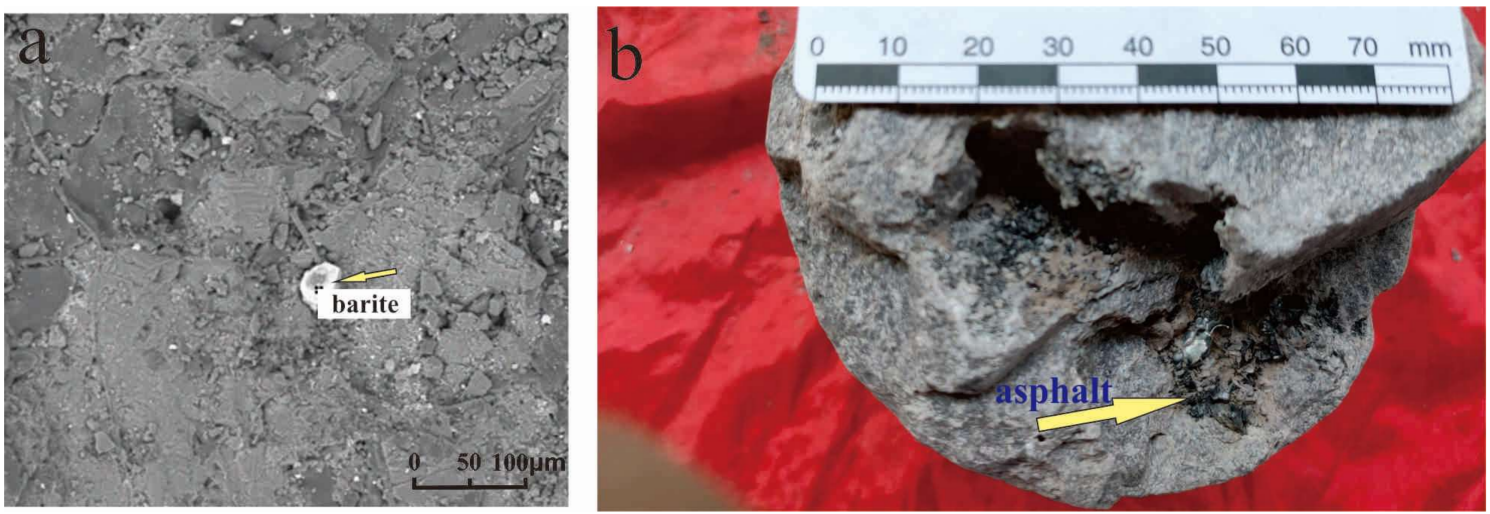

Figure 3. SEM image of barite and core image of asphalt. (a) Barite under SEM. (b) Vug filling with asphalt. 
Table 1. Elemental composition of asphalt and barite.

\begin{tabular}{|c|c|c|c|c|c|c|c|c|c|c|c|c|c|}
\hline Well & Depth (m) & Lithologies & Magnification & Material & $\mathrm{C} / \%$ & $\mathrm{O} / \%$ & $\mathrm{~S} / \%$ & $\mathrm{Cl} / \%$ & $\mathrm{Ca} / \%$ & $\mathrm{Au} / \%$ & $\mathrm{Si} / \%$ & $\mathrm{Al} / \%$ & $\mathrm{Ba} / \%$ \\
\hline MX42 & 4651.2 & $\begin{array}{l}\text { Fine-medium } \\
\text { crystalline dolostone }\end{array}$ & 600 & Barite & 9.95 & 28.45 & 10.33 & 0 & 0.44 & 8.55 & 0.34 & 0.45 & 41.49 \\
\hline MX42 & 4651.2 & $\begin{array}{c}\text { Fine-medium } \\
\text { crystalline dolostone }\end{array}$ & 600 & Asphalt or oil trace & 80.3 & 5.19 & 8.13 & 0.41 & 0.49 & 5.49 & 0 & 0 & 0 \\
\hline
\end{tabular}

Table 2. The order degrees of various dolostones.

\begin{tabular}{cccc}
\hline Well & $\begin{array}{c}\text { Depth } \\
(\mathbf{m})\end{array}$ & Lithologies & Order Degrees of Dolostones ( $)$ \\
\hline MX42 & 4650.50 & Meso-coarse crystalline dolostone & 0.93 \\
MX42 & 4651.20 & Meso-coarse crystalline dolostone & 0.82 \\
MX42 & 4655.42 & Fine-medium crystalline dolostone & 0.69 \\
MX42 & 4655.62 & Meso-coarse crystalline dolostone & 0.93 \\
MX42 & 4659.68 & Fine-medium crystalline dolostone & 0.79 \\
MX108 & 4671.8 & Fine-medium crystalline dolostone & 0.77 \\
MX108 & 4689.46 & Meso-coarse crystalline dolostone & 0.84 \\
MX108 & 4690.78 & Meso-coarse crystalline dolostone & 0.82 \\
\hline
\end{tabular}

\subsubsection{Dolomitic Limestone}

The dolomitic limestone was partially dolomitized bioclastic limestone. The matrix between particles was mostly micrite calcite. The dolomitized particles were scattered in the matrix. For the dolomitic limestone part, the color of the limestone part under cathode luminescence was null (Figure 2F,f), and the dolostone part was dark red. These dolomitic limestones could be observed in the Q1 and Q2 member.

\subsubsection{Limestone}

Limestone is common in the Qixia Formation, dominated by bioclastic limestone (Figure 2H). The skeletal types and full organisms observed under the microscope included foraminifera, algae, Fusulinella sp., bivalves, brachiopods, and echinoderms. The intraclastic limestone and pelletoid limestone could also be observed in the Qixia Formation.

The bioclastic limestones and marlstones were interbedded in the lower part of the Q1 Member. The bioclastic limestone and intraclastic limestone developed in the upper part of Q1 Member. There was mainly sparry bioclastic limestone, micro-sparry pelletoid limestone, and sparry intraclastic limestone in the Q2 Member.

\subsection{Elements}

The composition of rare earth elements (REEs) of the carbonate rocks from the Qixia Formation in the study area is shown in Table 3. The total REE contents were in the range of $0.26-0.60 \mu \mathrm{g} / \mathrm{g}$, in which the contents of heavy rare earth elements were $0.09-0.30 \mu \mathrm{g} / \mathrm{g}$, and the contents of light rare earth elements ranged from 0.12 to $0.30 \mu \mathrm{g} / \mathrm{g}$. The light rare earth/heavy rare earth ratios ranged from 0.66 to 1.81 . The $\delta$ Eu values were 1.04-7.43, and the $\delta$ Ce values were $0.77-0.90$ (Table 3 ). REE patterns of dolostones and limestones without diagenetic alteration are shown in Figure 4. The REE patterns of fine-medium crystalline and meso-coarse crystalline dolostone were characterized by positive Eu anomalies, compared with dolomitic limestone and limestone. In the REE pattern of meso-coarse crystalline dolostone, heavy rare earth elements were relatively enriched (Figure 4). At the same time, the $\delta$ Eu values of meso-coarse crystalline dolostone and fine-medium crystalline dolostone were different. 
Table 3. Rare earth element composition of carbonate rocks from the Qixia Formation.

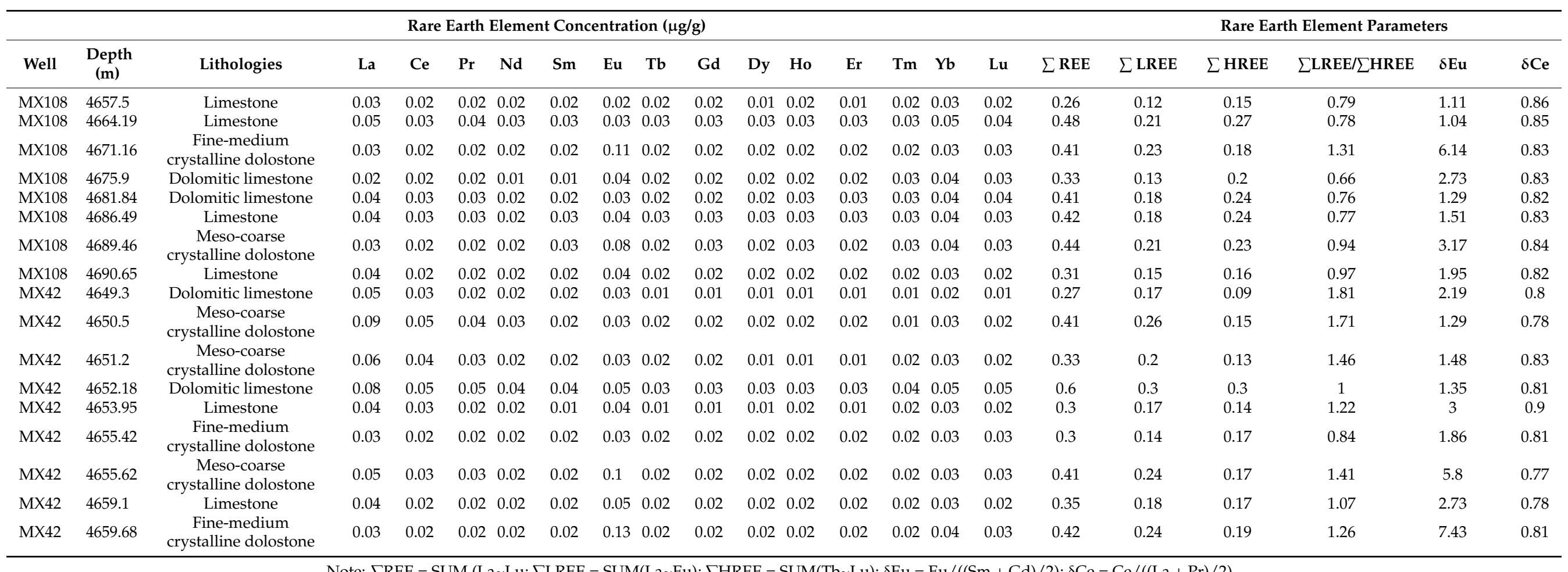

Note: $\sum$ REE = SUM $\left(\mathrm{La} \sim \mathrm{Lu} ; \sum \mathrm{LREE}=\mathrm{SUM}(\mathrm{La} \sim \mathrm{Eu}) ; \sum \mathrm{HREE}=\mathrm{SUM}(\mathrm{Tb} \sim \mathrm{Lu}) ; \delta \mathrm{Eu}=\mathrm{Eu} /((\mathrm{Sm}+\mathrm{Gd}) / 2) ; \delta \mathrm{Ce}=\mathrm{Ce} /((\mathrm{La}+\mathrm{Pr}) / 2)\right.$. 


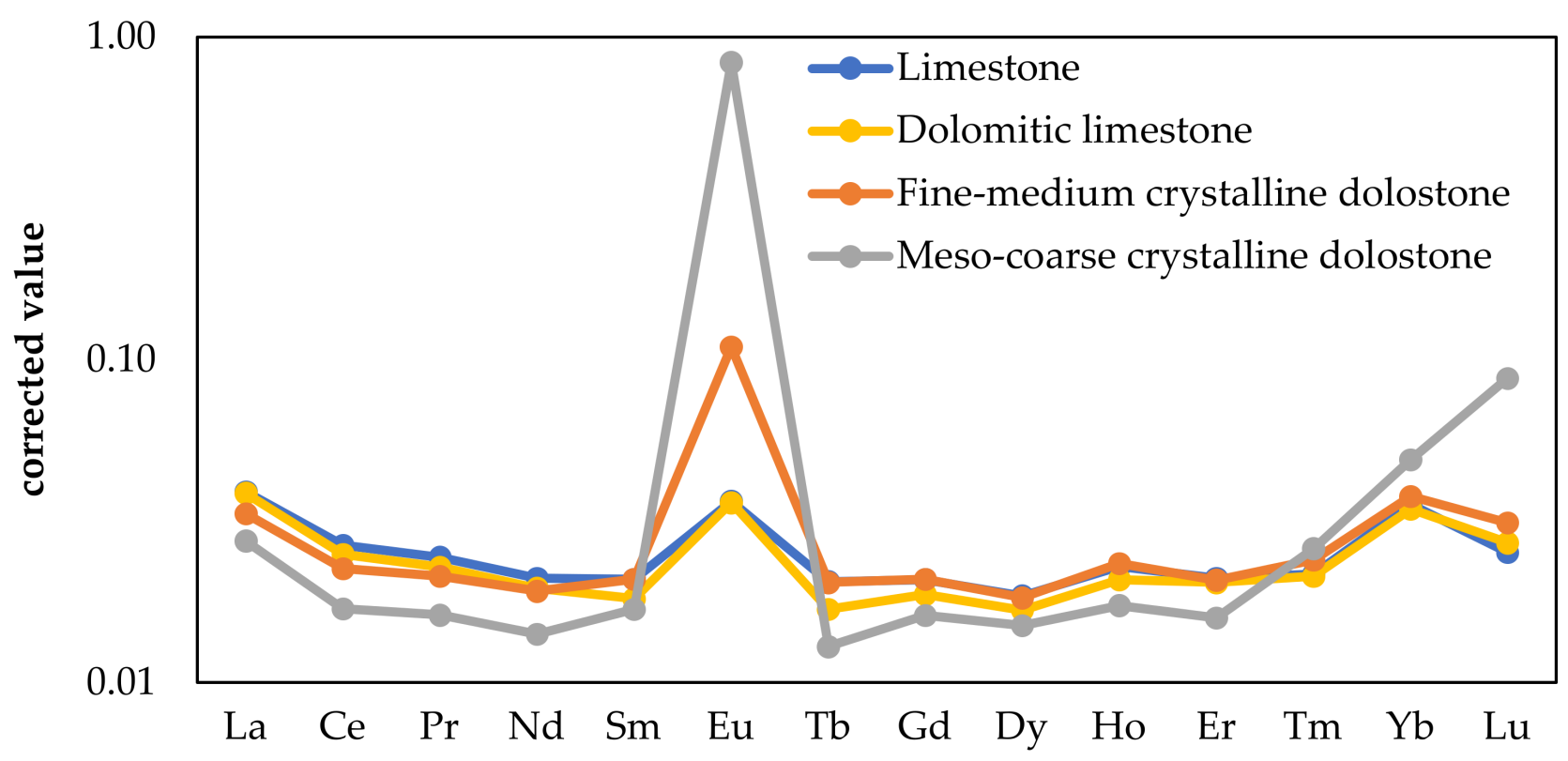

Figure 4. The REE patterns of carbonate rocks from the Qixia Formation (the normalizing values used were those of North-American shale).

The contents of trace elements are shown in Figure 5. It can be seen that the strontium content in limestone was from 349.48 to $699.00 \mathrm{ppm}$, with an average value of $476.05 \mathrm{ppm}$. The strontium content in dolomitic limestone ranged from 335.58 to 431.19 ppm with an average of $395.15 \mathrm{ppm}$. The strontium content of fine-medium crystalline dolostone was from 88.36 to $225.49 \mathrm{ppm}$, with an average value of $135.07 \mathrm{ppm}$. The strontium content of meso-coarse crystalline dolostone was from 80.02 to $132.87 \mathrm{ppm}$, with the average value of $104.34 \mathrm{ppm}$. The amount of manganese in dolomitic limestone was from 51.61 to $61.21 \mathrm{ppm}$, with the average value of $55.20 \mathrm{ppm}$. The amount of manganese of limestone was from 37.00 to $132.53 \mathrm{ppm}$, with an average value of $72.27 \mathrm{ppm}$. Manganese contents of the finemedium crystalline dolostones ranged from $107.12 \mathrm{ppm}$ to $166.52 \mathrm{ppm}$, with an average value of $136.97 \mathrm{ppm}$. Manganese contents of the meso-coarse crystalline dolostones ranged from 240.65 to $411.97 \mathrm{ppm}$, with an average value of $325.26 \mathrm{ppm}$.
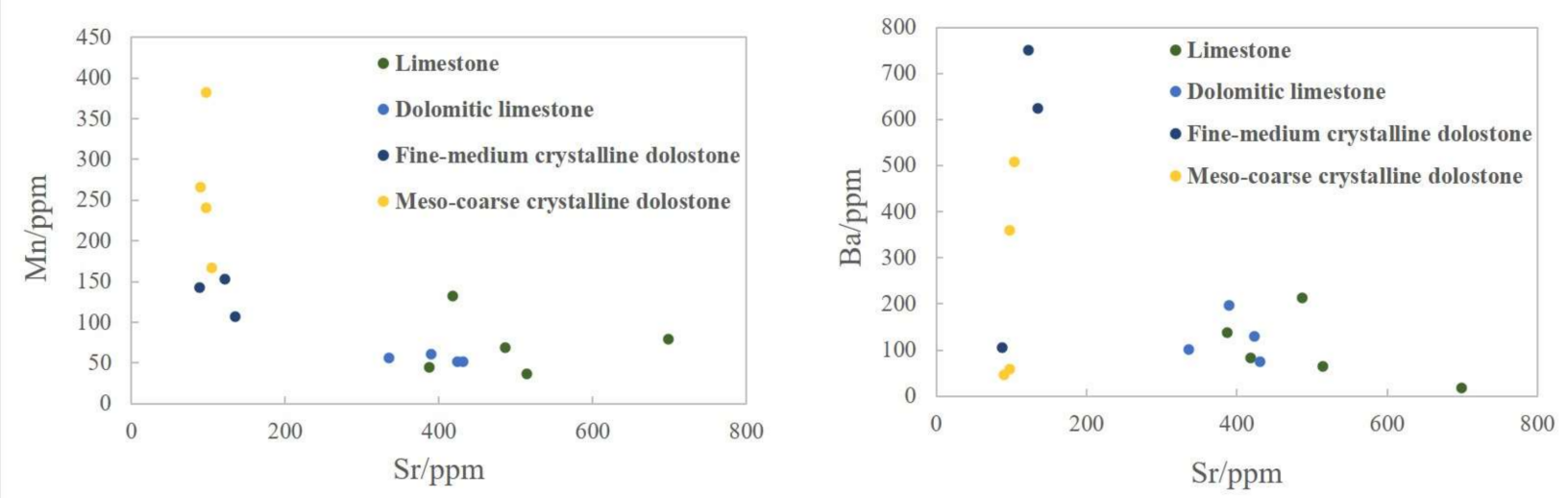

Figure 5. Sr, Mn, and Ba value cross plots of different lithologies. 


\subsection{C, O, Sr Isotopes}

The carbon and oxygen stable isotope values of limestone, fine-medium crystalline dolostone, and meso-coarse crystalline dolostone in the study area are shown in Table 4. The $\delta^{18} \mathrm{O}$ of limestone was from $-5.25 \%$ to $-8.53 \%$, with an average value of $-6.92 \%$. The $\delta^{13} \mathrm{C}$ of limestone was from $-2.62 \%$ to $4.35 \%$. The $\delta^{18} \mathrm{O}$ of fine-medium crystalline dolostone was from $-7.18 \%$ to $-8.53 \%$, with an average value of $-7.96 \%$, and the $\delta^{13} \mathrm{C}$ of fine-medium crystalline dolostone was from $-1.21 \%$ to $4.99 \%$, with an average value of $1.18 \%$. The $\delta^{18} \mathrm{O}$ of meso-coarse crystalline dolostone ranged from $-7.26 \%$ to $-8.35 \%$, with an average value of $-7.64 \%$, and the $\delta^{13} \mathrm{C}$ of meso-coarse crystalline dolostone ranged from $-1.32 \%$ to $4.19 \%$.

Table 4. Carbon, oxygen, and strontium isotope values of carbonate rocks in the Qixia Formation.

\begin{tabular}{|c|c|c|c|c|c|}
\hline Well & Depth (m) & Lithologies & $\delta^{13} C_{\text {V-PDB }} \%$ & $\delta^{18} \mathrm{O}_{\text {V-PDB }} \%$ & ${ }^{87} \mathrm{Sr} /{ }^{86} \mathrm{Sr}$ \\
\hline MX42 & 4649.3 & Dolomitic limestone & -1.32 & -7.26 & 0.707781 \\
\hline MX42 & 4650.5 & Meso-coarse crystalline dolostone & -1.21 & -7.3 & 0.708383 \\
\hline MX42 & 4651.2 & Meso-coarse crystalline dolostone & -1.21 & -7.23 & 0.70808 \\
\hline MX42 & 4652.18 & Dolomitic limestone & -1.19 & -8.08 & 0.707699 \\
\hline MX42 & 4655.42 & Fine-medium crystalline dolostone & -1.35 & -7.18 & 0.708412 \\
\hline MX42 & 4655.62 & Meso-coarse crystalline dolostone & 4.58 & -8.52 & 0.708181 \\
\hline MX42 & 4659.68 & Fine-medium crystalline dolostone & -1.41 & -6.99 & 0.708089 \\
\hline MX108 & 4657.5 & Limestone & 4.35 & -5.25 & 0.707121 \\
\hline MX108 & 4664.19 & Limestone & -2.62 & -8.53 & 0.70749 \\
\hline MX108 & 4671.16 & Fine-medium crystalline dolostone & 4.93 & -8.53 & 0.70799 \\
\hline MX108 & 4671.8 & Fine-medium crystalline dolostone & 4.99 & -8.06 & 0.708392 \\
\hline MX108 & 4681.84 & Dolomitic limestone & 3.61 & -6.65 & 0.707894 \\
\hline MX108 & 4689.46 & Meso-coarse crystalline dolostone & 4.19 & -8.35 & 0.708118 \\
\hline MX108 & 4690.78 & Meso-coarse crystalline dolostone & 3.73 & -8.64 & 0.708526 \\
\hline
\end{tabular}

Combined with the calculation method of ancient seawater temperature (Ts) proposed by Keith and Shackleton et al. [28,31], using the average value of $\delta^{18} \mathrm{O}$ of Quaternary marine carbonate rocks of $-1.2 \%$ as the standard for age correction, the Ts of the Qixia period could be calculated. The average $\delta^{18} \mathrm{O}$ value of the Qixia Formation was $-7.61 \%$. The difference between the $\delta^{18} \mathrm{O}$ value of the Quaternary marine carbonate rocks and that of the Qixia Formation was $-6.41 \%$. Then the actual test value was subtracted from the corrected value $\Delta \delta^{18} \mathrm{O}$, and the corrected $\delta^{18} \mathrm{O}_{\mathrm{CaCO}_{3}}$ value was obtained.

$$
\text { Ts }\left({ }^{\circ} \mathrm{C}\right)=15.976-4.2 \delta^{18} \mathrm{Ocaco}_{3}+0.13\left(\delta^{18} \mathrm{Ocaco}_{3}+0.2\right)^{2}\left(\delta^{18} \mathrm{Ocaco}_{3}\right)=\delta^{18} \mathrm{O}_{\mathrm{V}-\mathrm{PDB}} \%-\triangle \delta^{18} \mathrm{O}
$$

$\triangle \delta^{18} \mathrm{O}=$ The average value of $\delta^{18} \mathrm{O}_{\mathrm{V}-\mathrm{PDB}} \%-(-1.2 \%),(-1.2 \%)=$ Average $\delta^{18} \mathrm{O}$ of Quaternary marine carbonate rocks

According to the Formulas (1) and (2) [27-29,32], the ancient seawater temperature of the Qixia period in the study area was calculated (Table 5). As shown in Table 5, the Ts of the Qixia period was between 11.35 and $25.87^{\circ} \mathrm{C}$, with an average value of $21.26^{\circ} \mathrm{C}$. At the same time, the oxygen isotope values could also be used to calculate the temperature of the precipitation of carbonate minerals (Tc) [33].

$$
\mathrm{Tc}\left({ }^{\circ} \mathrm{C}\right)=13.85-4.54 \delta^{18} \mathrm{O}_{\mathrm{V}-\mathrm{PDB}} \% \text { o }+0.04\left(\delta^{18} \mathrm{O}_{\mathrm{V}-\mathrm{PDB}} \%\right)^{2}
$$

As shown in Table 5, the diagenetic temperature of fine-medium crystalline dolostone was between 48.77 and $55.49^{\circ} \mathrm{C}$. According to the geothermal gradient of $3{ }^{\circ} \mathrm{C} / 100 \mathrm{~m}[34,35]$, the burial depth was about $1600 \mathrm{~m}$.

The ${ }^{87} \mathrm{Sr} /{ }^{86} \mathrm{Sr}$ values of dolostones from the Qixia Formation were between 0.707121 and 0.708526 (Table 4). The ${ }^{87} \mathrm{Sr} /{ }^{86} \mathrm{Sr}$ values of limestones ranged from 0.707121 to 0.70749 , with an average value of 0.707306 . The ${ }^{87} \mathrm{Sr} /{ }^{86} \mathrm{Sr}$ values of dolomitic limestones were between 0.707699 and 0.707894 , with an average value of 0.707791 . The ${ }^{87} \mathrm{Sr} /{ }^{86} \mathrm{Sr}$ values of fine-medium crystalline dolostones were between 0.70799 and 0.708189 , with an average 
value of 0.708113 . The ${ }^{87} \mathrm{Sr} /{ }^{86} \mathrm{Sr}$ values of meso-coarse crystalline dolostones were from 0.708383 to 0.708526 , with an average value of 0.708455 . It can be seen that the ${ }^{87} \mathrm{Sr} /{ }^{86} \mathrm{Sr}$ values of dolostone were heavier than those of dolomitic limestone and limestone, while the ${ }^{87} \mathrm{Sr} /{ }^{86} \mathrm{Sr}$ values of meso-coarse crystalline dolostone were heavier than that of finemedium crystalline dolostone (Table 4 ).

Compared with the range of ${ }^{87} \mathrm{Sr} /{ }^{86} \mathrm{Sr}$ in seawater at the depositional period [36,37], the ${ }^{87} \mathrm{Sr} /{ }^{86} \mathrm{Sr}$ values of limestones, dolomitic limestones, and some fine crystalline dolostones in the Qixia Formation were mostly within the range of Sr isotope composition of contemporaneous seawater (Figure 6). The ${ }^{87} \mathrm{Sr} /{ }^{86} \mathrm{Sr}$ was prone to increase with the dolomitization. The ${ }^{87} \mathrm{Sr} /{ }^{86} \mathrm{Sr}$ values of meso-coarse crystalline dolostones in the Qixia Formation were generally heavier than those of fine-crystalline dolostone, dolomitic limestone, and limestone (Figure 6).

Table 5. The calculated ancient seawater temperature and diagenetic temperature based on oxygen isotopes.

\begin{tabular}{|c|c|c|c|c|c|c|}
\hline Well & Lithologies & Depth (m) & $\delta^{18} \mathrm{O}$ V-PDB $\%$ & $\delta^{18} \mathrm{O}-\mathrm{Caco}_{3}$ & $\begin{array}{l}\text { Ancient Seawater } \\
\text { Temperature }\left({ }^{\circ} \mathrm{C}\right)\end{array}$ & $\begin{array}{c}\text { Theoretical } \\
\text { Diagenetic } \\
\text { Temperature }\left({ }^{\circ} \mathrm{C}\right)\end{array}$ \\
\hline MX108 & $\begin{array}{c}\text { Meso-coarse } \\
\text { crystalline dolostone }\end{array}$ & 4690.78 & -8.64 & -2.23 & 25.88 & 56.06 \\
\hline MX42 & $\begin{array}{l}\text { Fine-medium } \\
\text { crystalline dolostone }\end{array}$ & 4659.68 & -6.99 & -0.58 & 18.43 & 47.54 \\
\hline MX108 & Limestone & 4657.5 & -5.25 & 1.16 & 11.34 & 38.79 \\
\hline MX108 & Limestone & 4664.19 & -8.53 & -2.12 & 25.36 & 55.49 \\
\hline MX42 & $\begin{array}{l}\text { Fine-medium } \\
\text { crystalline dolostone }\end{array}$ & 4655.42 & -7.18 & -0.77 & 19.25 & 48.51 \\
\hline MX42 & $\begin{array}{l}\text { Meso-coarse } \\
\text { crystalline dolostone }\end{array}$ & 4651.2 & -7.23 & -0.82 & 19.47 & 48.77 \\
\hline MX42 & Dolomitic limestone & 4652.18 & -8.08 & -1.67 & 23.27 & 53.14 \\
\hline MX108 & $\begin{array}{l}\text { Fine-medium } \\
\text { crystalline dolostone }\end{array}$ & 4671.16 & -8.53 & -2.12 & 25.36 & 55.49 \\
\hline MX108 & $\begin{array}{l}\text { Fine-medium } \\
\text { crystalline dolostone }\end{array}$ & 4671.8 & -8.06 & -1.65 & 23.18 & 53.04 \\
\hline MX42 & $\begin{array}{l}\text { Meso-coarse } \\
\text { crystalline dolostone }\end{array}$ & 4655.62 & -8.52 & -2.11 & 25.31 & 55.43 \\
\hline MX108 & Dolomitic limestone & 4681.84 & -6.65 & -0.24 & 16.98 & 45.81 \\
\hline MX42 & Dolomitic limestone & 4649.3 & -7.26 & -0.85 & 19.60 & 48.92 \\
\hline MX42 & $\begin{array}{c}\text { Meso-coarse } \\
\text { crystalline dolostone }\end{array}$ & 4650.5 & -7.3 & -0.89 & 19.78 & 49.12 \\
\hline MX108 & $\begin{array}{l}\text { Meso-coarse } \\
\text { crystalline dolostone }\end{array}$ & 4689.46 & -8.35 & -1.94 & 24.52 & 54.55 \\
\hline
\end{tabular}

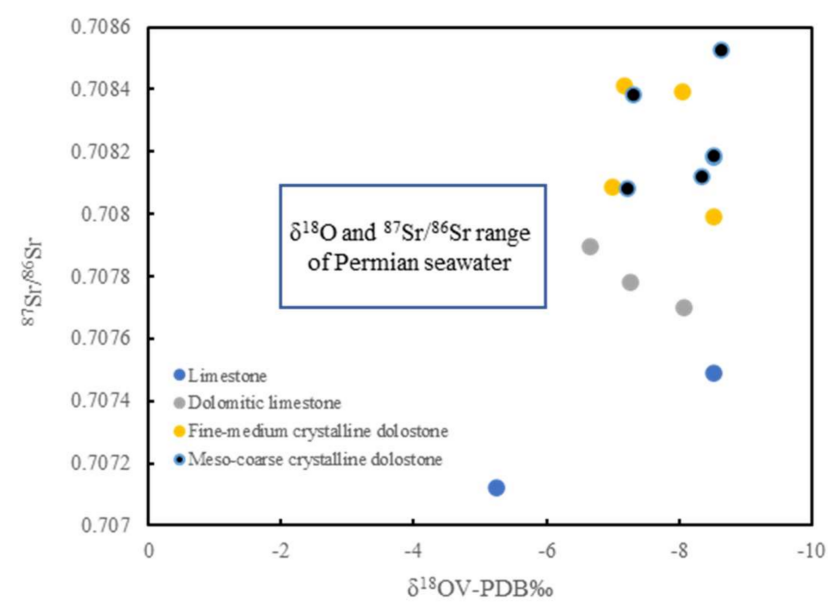

Figure 6. The cross plot of oxygen isotope and strontium isotope. 

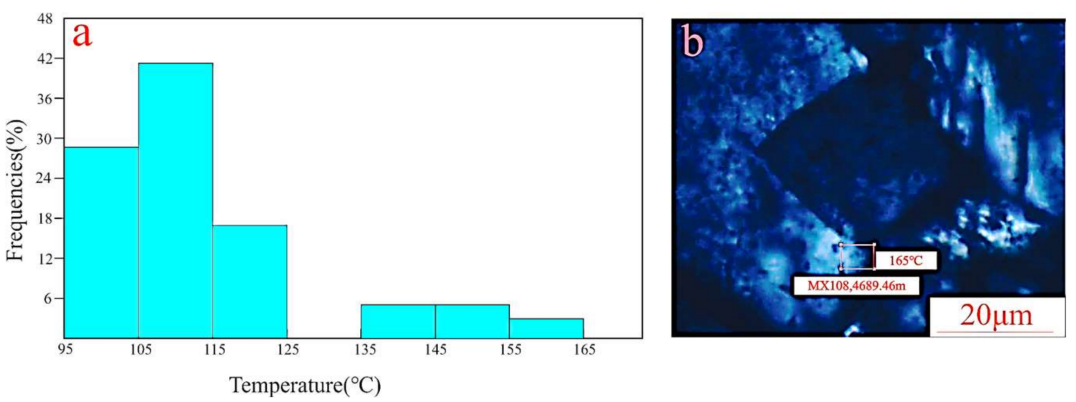

Figure 7. Homogenization temperature of fluid inclusion. (a) Distribution histogram of the homogenization temperature of fluid inclusion within dolomites; (b) image of fluid inclusions in MX108 well $4689.46 \mathrm{~m}$.

\subsection{Homogenization Temperature of Fluid Inclusions}

The homogenization temperatures $\left(T_{h}\right)$ of fluid inclusions within dolomites of the Qixia Formation are shown in Figure 7a. The fluid inclusions within the dolomite crystal are shown in Figure $7 \mathrm{~b}$. It was found that there were two obvious Th intervals, as shown in Figure 7a. The first interval was $95-125^{\circ} \mathrm{C}$, with an average $\mathrm{T}_{\mathrm{h}}$ of $108^{\circ} \mathrm{C}$. The second interval was $135-165^{\circ} \mathrm{C}$, with an average $\mathrm{Th}$ of $148^{\circ} \mathrm{C}$.

\section{Discussion}

\subsection{Timing and Stages of Dolomitization}

In the study area, fine-medium crystalline dolostones and meso-coarse crystalline dolostones were found in the Qixia Formation. The carbon isotope values of these two types of dolostones were close to those of limestones. The $\delta^{13} \mathrm{C}$ of limestone was from $-2.62 \%$ o to $4.35 \%$. The carbon isotope of Permian seawater was $2 \sim 5 \%$ [38]. It indicates that they have the same carbon source [39-41]. The $\delta^{13} \mathrm{C}$ values of dolostones were mostly positive (Table 4), indicating that meteoric water or organic matter was rarely involved in the dolomitization [42,43].

Through the analysis of crystal morphology, the degrees of crystal automorphism of fine-medium crystalline dolostones were found to be relatively poor, with a subhedral texture. The order degrees of dolomites in the fine-medium crystalline dolostones were relatively low, ranging from 0.69 to 0.79 . The color of fine-medium crystalline dolostone under cathode luminescence was dark red, showing low Mn concentration. There was a Eu positive anomaly observed in the fine-medium crystalline dolostone, indicating a reducing environment. Meanwhile, the calculated diagenetic temperature of the finemedium crystalline dolostone was from 48.77 to $55.49^{\circ} \mathrm{C}$, using the oxygen isotope. These characteristics show that the fine-medium crystalline dolostones formed under a relatively low temperature, with incomplete dolomitization $[44,45]$.

The crystal morphology of meso-coarse crystalline dolostone was euhedral, with a straight edge. There was also a cloudy center and a bright rim structure of these dolomites. The order degrees of these dolomites were relatively high, ranging from 0.82 to 0.93 . The color of meso-coarse crystalline dolostone under cathode luminescence was orange. There was a distinct $\mathrm{Eu}$ positive anomaly observed in the meso-coarse crystalline dolostone. The content of strontium decreases with the dolomitization [36,46,47]. In terms of the strontium contents in the two types of dolostones (Figure 5), the strontium contents of the meso-coarse crystalline dolostones were higher than that of fine-medium crystalline dolostone, indicating that the dolomitized fluids of the two types of dolostones might be different. The Mn contents of meso-coarse crystalline dolostones were significantly higher than that of the fine-medium crystalline dolostones, dolomitic limestones, and limestones (Figures 5 and 8). The content of strontium in dolostone has a negative correlation with the content of magnesium $[42,46,48]$. This trend results because the ionic radius of strontium (the ionic radius of strontium is $0.113-0.132 \mathrm{~nm}$ ) is relatively close to that of calcium (the ionic radius of calcium is $0.009-0.118 \mathrm{~nm}$ ), while the ionic radius of magnesium is $0.065-0.087 \mathrm{~nm}$ [3]. Therefore, strontium ions will replace calcium ions 
and leave magnesium ions. The relatively high Mn contents indicate a relatively reducing environment and strong diagenetic alteration. During the deposition process, the oxygen isotope values decrease with the increase of temperature [49], assuming that the salinity of ancient seawater is basically unchanged. The more negative $\delta^{18} \mathrm{O}$ (Figure 6) and relatively high temperature of fluid inclusions enclosed in dolomites shows there was a diagenetic environment with a high temperature (Figure 7a). The relatively heavy ${ }^{87} \mathrm{Sr} /{ }^{86} \mathrm{Sr}$ values of meso-coarse crystalline dolostone might be related to the presence of exogenous ${ }^{87} \mathrm{Sr}$ input during dolomitization. These characteristics indicate that meso-coarse crystalline dolostone formed in a strong reducing environment with a relatively high temperature. The dolomitization of the meso-coarse crystalline dolostone was complete, and dolomite crystals of these dolostones were close to that of ideal dolomites.

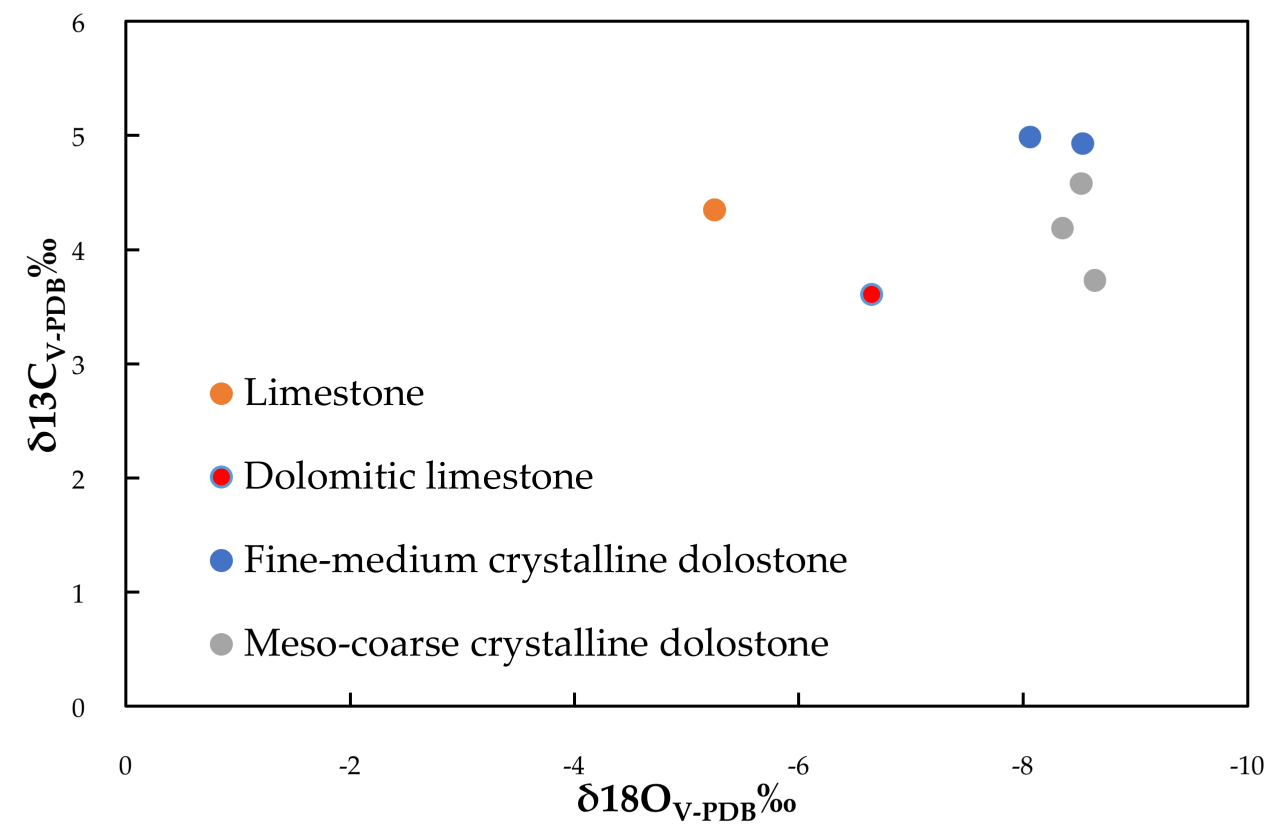

Figure 8. Cross plot of carbon and oxygen isotopes.

Therefore, based on the analysis data, there were two phases of diagenetic fluid with different temperatures and geochemical composition in the diagenesis process of the Qixia Formation. The carbon and oxygen isotopes of the carbonate rocks from the Qixia Formation could be divided into two areas (Figure 8), showing the two phases of diagenetic fluid. The different Eu anomaly of the two populations of dolomites also indicates that there were two different diagenetic fluids (Figure 4) [41,42,50,51]. Meanwhile, the two intervals of homogenization temperatures of fluid inclusions could be seen in Figure 7a.

The paragenesis of dolostones from the Permian Qixia Formation in the central uplift of the Sichuan Basin can be determined by a diagenetic sequence. The asphalt filling fractures could be observed in the core and thin sections of the two types of dolostones (Table 1 and Figure 3), indicating that the timing of dolostone formation was earlier than that of oil and gas filling. Previous studies suggested that the hydrocarbons had charged into the Qixia Formation in the study area after Jurassic [51,52]. Therefore, the time of dolostone formation should be earlier than the Jurassic period.

Based on the above discussion, this study suggests that dolostone in the study area was formed in two stages during two periods. Fine-medium crystalline dolostone was formed in the shallow burial period. Meso-coarse crystalline dolostone was formed in the relatively deep burial environment before the Jurassic.

\subsection{Dolomitization of Dolostone Formed by Hydrothermal Fluids}

As discussed above, the dolostones in the Qixia Formation were dolomitized before the Jurassic period. The burial depth of the Qixia Formation in the study area during 
the Jurassic was about $2500 \mathrm{~m}$ [46], assuming the average geothermal gradient was the maximum value of $4{ }^{\circ} \mathrm{C} / 100 \mathrm{~m}$ [35]. The burial temperature of the Qixia Formation in this period was $100{ }^{\circ} \mathrm{C}$. The homogenization temperatures of fluid inclusions within dolomites ranged from 95 to $165{ }^{\circ} \mathrm{C}$ (Figure 7), which is significantly higher than the burial temperature of $100{ }^{\circ} \mathrm{C}$. The high homogenization temperature indicates that the formation of dolostone may be affected by local high-temperature conditions or thermal events $[40,41,53,54]$. At the same time, the oxygen isotope values of the two populations of dolomites were obviously negative. Excluding the meteoric water, the negative oxygen isotope may be affected by the hydrothermal fluid $[40,41,47]$. The oxygen isotope value of dolostones influenced by hydrothermal fluid usually was more negative than that of limestone and reflux-seepage dolostone, e.g., the hydrothermal dolostone with $\delta^{18} \mathrm{O}$ of below $-7 \%$ [55] and coarse crystalline dolomite with $\delta^{18} \mathrm{O}$ of $-7.82 \%$ [3] in the Maokou Formation in the central uplift of the Sichuan basin. The $\delta^{18} \mathrm{O}$ of fine crystalline dolostone $(-7.18 \%$ to $-8.53 \%)$ and meso-coarse crystalline dolostone $(-7.26 \%$ to $-8.35 \%)$ in this study were more negative than that of limestone (average value of $-6.92 \%$ ). However, the $\delta^{18} \mathrm{O}$ of hydrothermal dolostones in other basins is usually below $-10 \%$ [56,57], the relatively heavier $\delta^{18} \mathrm{O}$ in the study might have been influenced by the high salinity. Strontium isotope could be used to identify the occurrence of hydrothermal fluids [8]. The $\mathrm{Sr}$ isotopes of meso-coarse crystalline dolostone were heavier than that of fine-medium crystalline dolostone and were beyond the range of Sr isotope of contemporaneous seawater (Figure 6). Barite was observed under a microscope. Meanwhile, there was the obvious Eu positive anomaly of the two types of dolostone and the heavy rare earth elements were relatively enriched in the meso-coarse crystalline dolostones, indicating a strong reducing environment probably caused by the hydrothermal fluids [32,58-60]. These characteristics indicate that the digenesis of the two types of dolostones were influenced by hydrothermal fluids. According to the oxygen isotopes, with values beyond $-10 \%$, and distinct Eu positive anomaly of these dolomites, the hydrothermal fluid was of relatively high salinity and reducing capacity, with the source of sealed seawater in the strata.

Combined with the regional tectonic setting, Emeishan basalt erupted strongly from the late depositional period of the Early Permian Maokou Formation to the early stage of the Late Permian in the southwest area of the Sichuan Basin $[34,61]$. Therefore, the local high-temperature condition may be closely related to the eruption of Emeishan basalt. The high temperature of fluid inclusion with a range of $135-165{ }^{\circ} \mathrm{C}$ (Figure 7) and the relatively high order degrees of dolomites indicate that the formation of meso-coarse crystalline dolostone occurred in the period of hydrothermal fluid activity during the eruption of Emeishan basalt. However, based on the U-Pb isotope dating of dolomite, the age of the hydrothermal dolomite formation in the Qixia Formation in the southwest area of Sichuan basin was suggested at about 216-206 Ma [62], indicating the hydrothermal dolomite formation occurred after the eruption of Emeishan basalt. Therefore, in this study it was determined that the meso-coarse crystalline dolomites of the Qixia Formation might have formed in the relatively deep burial diagenesis, after the moment of Emeishan basalt eruption. At the same time, saddle-shaped dolostone and matrix dolostone were also formed [63,64].

Through the statistics of a large number of hydrothermal dolostones in the world, Davies and Smith (2006) found that nearly $80 \%$ of hydrothermal dolomitization occurs during early diagenesis or shallow burial $[32,39,65]$. The homogenization temperatures of fluid inclusions within fine-medium crystalline dolostone were mostly between 95 and $125^{\circ} \mathrm{C}$ (Figure 7a), indicating that the formation of dolomite may be related to the early stage of hydrothermal fluid activity, before the timing of meso-coarse crystalline dolomite formation. According to the heat flow recovery results of some typical wells in the study area [66], the temperature in the study area began to increase rapidly from the Permian period. The regional heat flow value suddenly increased at about $259 \mathrm{Ma}$, and then began to decrease significantly [66]. The rapid increase of the heat flow value resulted from the Emei ground fissuring movement in the Sichuan Basin during the Late Permian-Late Triassic, 
which was characterized by extensional fault activity [67]. The peak temperature of hydrothermal fluid in that period occurred at the moment of Emeishan basalt eruption. Some high-temperature fluid inclusions within calcite veins in the fine crystalline dolostones might have been captured in the period of this geological event. The relatively low $\mathrm{Mn}$ content of fine-medium crystalline dolostone and the low abnormal value of Eu positive anomaly (Figure 4) indicate that the diagenetic temperature of fine-medium crystalline dolostones was lower than that of meso-coarse crystalline dolostones. The formation of fine-medium crystalline dolostone might have occurred in the early stage of the Emeishan basalt eruption, during the stage of hydrothermal fluid rising from lower strata in the depositional period of the Q2 Member (calculated from the burial depth).

\subsection{The Influence of Two Stages of Hydrothermal Fluid Activity on the Dolostone Formation}

Through the well-to-well correlation using the well cuttings, the fine-medium crystalline dolostones were found to be distributed along the sequence boundary between Q1 and Q2 Members, with good lateral continuity (Figure 1d). During the deposition of the Q1 Member, a large-scale shoal was developed in the study area. The bioclastic limestones with good physical properties were developed at the top of the Q1 Member [26]. As the consequence of the Emei ground fissuring movement, the hydrothermal fluid related to the mantle plume continuously charged into the Qixia Formation through the faults $[18,68]$. In the early stage of hydrothermal fluid activity, the hydrothermal fluids flowed laterally in the bioclastic limestones along the sequence boundary, which prompted the dolomitization and led to the layered distribution of fine-medium crystalline dolostone.

During the hydrothermal fluid activity after the Permian, meso-coarse crystalline dolostone formed. It can be seen that the meso-coarse crystalline dolostones are not distributed laterally as fine-medium-grained dolostone but were massive and locally distributed (Figure 1d), mainly distributed along faults [18,40,54,65,69-71]. During the formation of the meso-coarse crystalline dolostones, the hydrothermal fluid moved upward rapidly through the fracture. When the hydrothermal fluid passing through the Q1 Member, because the porosity had been very low as the result of diagenesis, the hydrothermal fluid could not move rapidly laterally. The dolomitization induced by the second stage of hydrothermal fluid only occurred along the fault zone.

The dolomitization models of the dolostones from the Qixia Formation following the two stages of hydrothermal fluid activity were established in the study (Figures 9 and 10).

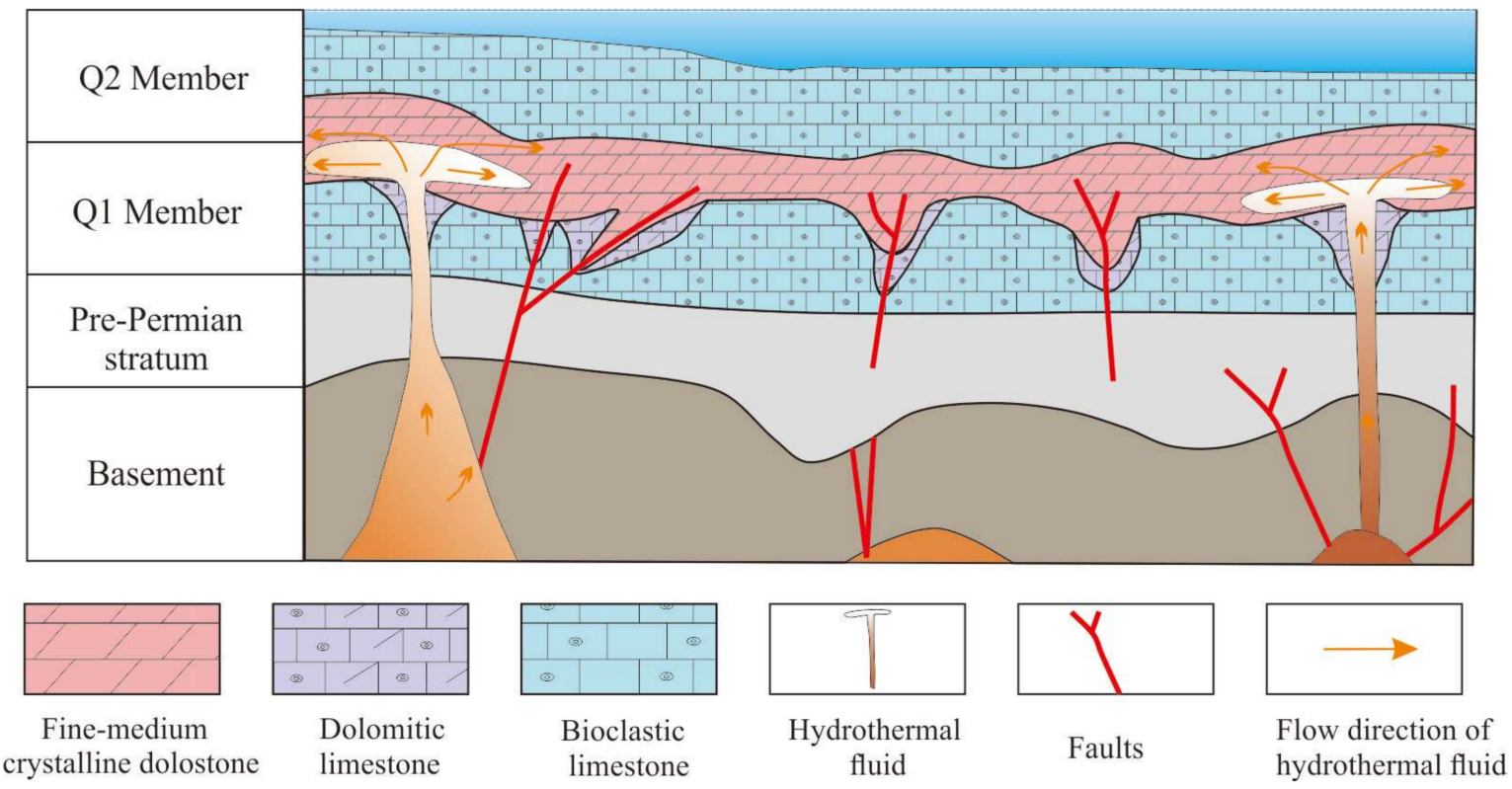

Figure 9. Genetic model of dolostone formation affected by the first stage of hydrothermal fluid. 


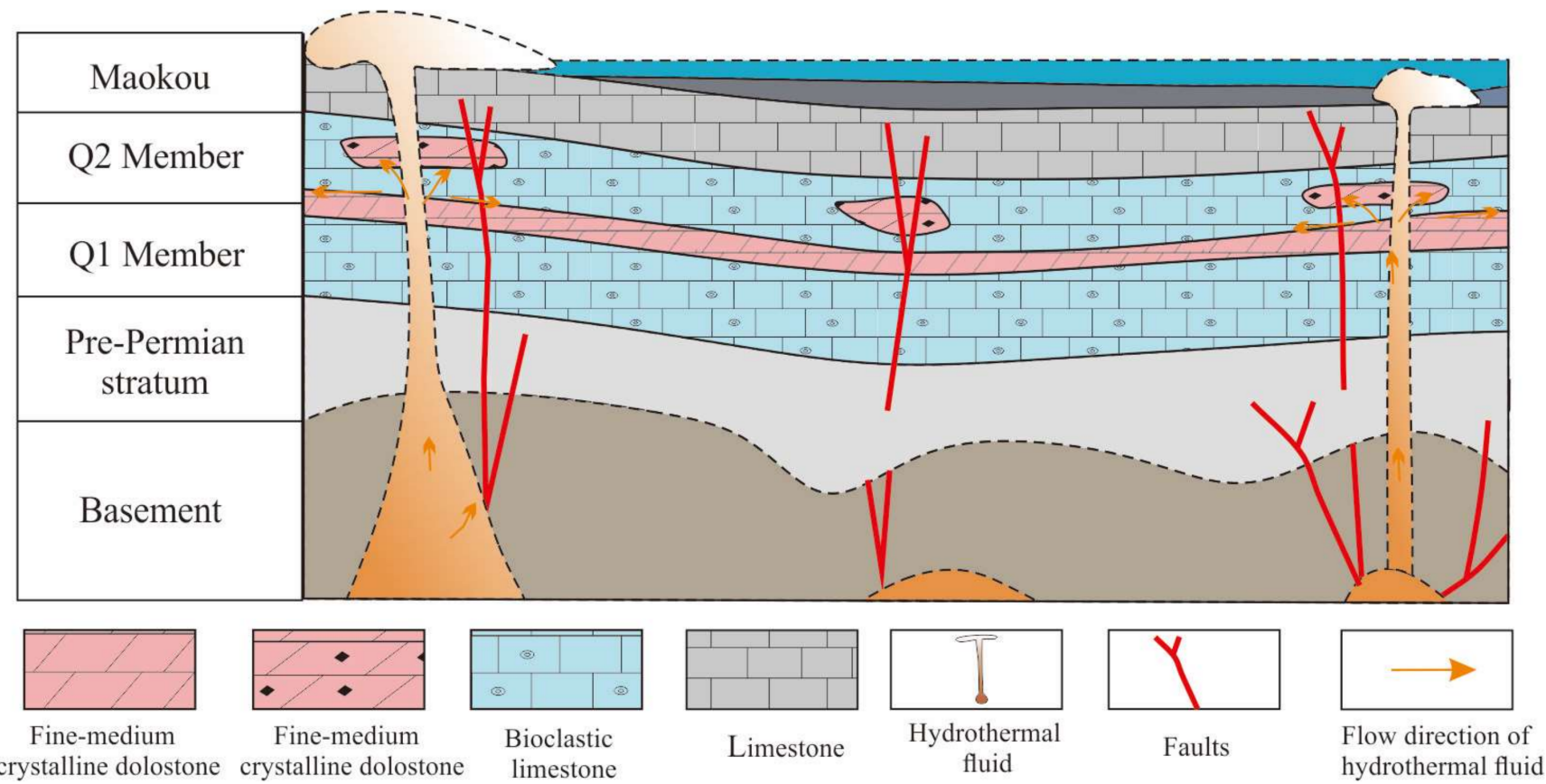

Figure 10. Genetic model of dolostone formation affected by phase II fluid.

\section{Conclusions}

The dolostone of the Qixia Formation in the central uplift of Sichuan Basin formed in two stages. The fine-medium crystalline dolostone formed in the shallow burial environment. The meso-coarse crystalline dolostone formed in a relatively deep burial environment.

The genesis of the dolostones from the Qixia Formation in the central uplift of the Sichuan Basin was related to hydrothermal fluid activity.

The formation of dolostones from the Qixia Formation in the central uplift of the Sichuan Basin was affected by two-stages of hydrothermal fluid activity. In the first stage, diagenetic fluid entered into the Qixia Formation and flowed laterally along the sequence boundary at the top of the Q1 Member, resulting in the formation of fine-medium crystalline dolostone. In the late diagenesis, high-temperature diagenetic fluids passed through the Qixia Formation, leading to the formation of meso-coarse crystalline dolostones along the faults.

Author Contributions: Conceptualization, H.D. and M.F.; Methodology, M.F.; Software, D.W.; Validation, M.F., H.D. and D.W.; Formal Analysis, M.F.; Investigation, H.G.; Resources, P.H.; Data Curation, W.X. and P.C.; Writing-Original Draft Preparation, P.C.; Writing-Review \& Editing, M.F.and P.C.; Visualization, M.F.; Supervision, H.D.; Pro-ject Administration, M.F.; Funding Acquisition, P.H. All authors have read and agreed to the published version of the manuscript.

Funding: This research was funded by [PetroChina Southwest oil \& Gasfield Company, Research Institute of Exploration and Development] grant number [XNS-JS2020-071].

Institutional Review Board Statement: The study was conducted according to the guidelines of the Declaration of Helsinki and approved by the Institu-tional Review Board (or Ethics Committee) of PetroChina Southwest oil \& Gasfield Company (protocol code: 2020-56205 and date of approval: 2 September 2020).

Informed Consent Statement: Informed consent was obtained from all subjects involved in the study.

Data Availability Statement: No new data were created or analyzed in this study. Data sharing is not applicable to this article. 
Acknowledgments: This research was supported by PetroChina Southwest oil and Gasfield Company. We thank PetroChina Southwest oil and Gasfield Company of China for providing rock samples. We thank the State Key Laboratory of Oil and Gas Reservoir Geology and Exploitation in China for the measurement.

Conflicts of Interest: The authors declare no conflict of interest.

\section{References}

1. Li, Z.; Ou, J.; Chen, X.; Li, F.; Wang, X.; Tan, X. Characteristics and main development controlling factors for lower Permian dolomite reservoirs in Chuanzhong region. Pet. Geol. Oilfield Dev. Daqing 2017, 36, 1-8.

2. Liu, J.; Zheng, H.; Liu, B.; Liu, H.; Shi, K.; Guo, R.; Zhang, X. Characteristics and genetic mechanism of the dolomite in the Middle Permian Maokou Formation, central Sichuan area. Acta Pet. Sin. 2017, 38, 386-398.

3. Wang, J.; Gu, Y.; Tao, Y.; Qiang, Z.; Qiang, S.; Jiang, C. The model of dolomitization jointly controlled by two-episode fluids in Maokou Formation in central Sichuan Basin. Acta Sedimentol. Sin. 2016, 34, 236-249.

4. Zhong, Y.; He, B.; Roland, M.; Xu, Y. CA-TIMS zircon U-Pb dating of felsic ignimbrite from the Binchuan section: Implications for the termination age of Emeishan Large Igneous Province. Lithos 2014, 204, 14-19. [CrossRef]

5. Tian, J.; Lin, X.; Guo, W.; Zhang, X.; Huang, P. Geological significance of oil and gas in the Permian basalt eruption event in Sichuan Basin, China. J. Chengdu Univ. Technol. 2017, 44, 14-20.

6. Feng, K.; Xu, S.; Chen, H.; Dong, Y. Genetic of Middle Permian dolomite in the southwestern Sichuan Basin: Evidence from strontium isotope and rare earth elements. Carsologica Sin. 2018, 37, 659-670.

7. Yang, Y.; Zhang, Y.; Xie, C.; Chen, C.; Zhang, X.; Chen, S.; Gao, Z. Hydrothermal effect of Middle Permian Qixia Formation in northwest Sichuan Basin and its effect on reservoirs. Lithol. Reserv. 2019, 31, 44-53.

8. Zhang, T.; Lin, J.; Han, Y.; Wang, Z.; Qin, J.; Zhang, R. Pattern of hydrothermal dolomitizationin the Middle Permian Maokou Formation, eastern Sichuan Basin, and its alteration on reservoirs herein. Oil Gas Geol. 2020, 41, 132-143.

9. Ma, X.; Yang, Y.; Wen, L.; Luo, B. Distribution and exploration direction of medium- and large-sized marine carbonate gas fields in Sichuan Basin, SW China. Pet. Explor. Dev. 2019, 46, 1-15. [CrossRef]

10. Yang, C.; Wen, L.; Wang, T.; Luo, B.; Li, M.; Tian, X.; Ni, Z. Timing of hydrocarbon accumulation time for paleo-oil reservoirs in Anyue gas field in Chuanzhong uplift. Oil Gas Geol. 2020, 41, 492-502.

11. Du, J.; Zou, C.; Xu, C.; He, H.; Shen, P.; Yang, Y.; Li, Y.; Wei, G.; Wang, Z.; Yang, Y. Theoretical and technical innovations in strategic discovery of a giant gas field in Cambrian Longwangmiao Formation of central Sichuan paleo-uplift, Sichuan Basin. Pet. Explor. Dev. 2014, 41, 268-277. [CrossRef]

12. Zou, C.; Du, J.; Xu, C.; Wang, Z.; Zhang, B.; Wei, G.; Wang, T.; Yao, G.; Deng, S.; Liu, J.; et al. Formation, distribution, resource potential and discovery of the Sinian-Cambrian giant gas field, Sichuan Basin, SW China. Pet. Explor. Dev. 2014, 41, 278-293. [CrossRef]

13. Kang, Y. The Formation and development of paleo-uplift in central Sichuan and its oil/gas prospect. Exp. Pet. Geol. 1988, 01, $12-23$.

14. Gan, Z. Discussion on Middle Sichuan Paleouplift from Paleozoic tectonic evolution in western Upper Yangtze Platform. Sichuan Geol. J. 1991, 02, 93-100.

15. Zhang, H.; Jiang, H.; Chen, Z.; Su, W. A review of the research status of Caledonian movement stages in Sichuan Basin and surrounding areas. Bull. Geol. Technol. 2020, 39, 118-126.

16. Mei, Q. Tectonic Evolution and Formation Mechanism of Leshan-Longnvsi Paleo-Uplift, Sichuan Basin; China University of Geosciences: Beijing, China, 2015.

17. Su, W.; Hu, S.; Jiang, Q.; Zhang, J.; Huang, S.; Jiang, H.; Shi, S.; Wang, K.; Chen, X.; Zhang, H.; et al. Sedimentary responses to the Dongwu movement and the influence of the Emeishan mantle plume in Sichuan Basin, Southwest China: Significance for petroleum geology. Carbonates Evaporites 2020, 35, 108. [CrossRef]

18. Li, Q.; Li, B.; Xu, S.; Mei, W. Source and accumulation processes of natural gases in the Qixia Formation in the Northwestern Sichuan Basin, SW China. J. Pet. Sci. Eng. 2021, 198, 108236. [CrossRef]

19. Shen, S.; Zhang, H.; Zhang, Y.; Yuan, D.; Chen, B.; He, W.; Mu, L.; Lin, W.; Wang, W.; Chen, J.; et al. Permian integrative stratigraphy and timescale of China. Sci. China Earth Sci. 2019, 62, 154-188. [CrossRef]

20. Liu, Z.; Yuan, B.; Huang, X.; Dai, X.; Lin, W.; Mao, L.; Qie, W.; Duan, X.; Li, Z.; Li, G. Division and correlation of Permian Foetation at Maoertang section in northwest Sichuan, China. J. Chengdu Univ. Technol. 2020, 47, 257-273.

21. Liu, W.; Zhong, D.; Sun, H.; Zeng, X.; Liang, X.; Hu, X.; Li, R.; Peng, S.; Song, Y. Sedimentary characteristics and paleogeomorphic responses of the middle Permian Qixia Formation in the northwestern Sichuan Basin. Acta Sedimentol. Sin. 2021, 39, $1275-1291$.

22. Zhong, Y.; Yang, Y.; Wen, L.; Luo, B.; Xiao, D.; Tan, X.; Zhao, L.; Li, M. Sedimentary environments controlled by tectonics and induced differential subsidence: A perspective in the Permian Liangshan and Qixia Formations, northwestern Sichuan Basin, China. J. Cent. South Univ. 2020, 27, 3398-3416. [CrossRef]

23. Huang, H.; He, D.; Li, Y.; Wang, B. The prototype and its evolution of the Sichuan sedimentary basin and adjacent areas during Liangshan and Qixia stages in Permian. Acta Petrol. Sin. 2017, 33, 1317-1337.

24. Wang, H.; Chi, Y.; Zhao, Z.; Jiang, Q.; Lu, G. Karst reservoirs developed in the Middle Permian Qixia Formation of Sichuan Basin and selection of exploration regions. Acta Pet. Sin. 2013, 34, 833-842. 
25. Hu, S.; Tang, X.; Liu, B.; Zhang, B.; Zhang, Y.; Su, C.; Lu, F.; Li, M. Sequence stratigraphic characteristics and geological significance of the Permian Qixia Stage in northwestern Sichuan Basin. J. Palaeogeogr. 2020, 22, 1109-1126.

26. Lu, F.; Tan, X.; Wang, L.; Tang, Q.; Xiao, D.; Dong, S.; Su, C.; Pan, Z. Characteristics and controlling factors of Dolomite Reservoirs within Shoal-Controlled Karst in the Middle Permian Qixia Formation, Central Sichuan Basin. Acta Sedimentol. Sin. 2021, 39, 456-469.

27. Keith, M.L.; Weber, J.N. Isotopic composition and environmental classification of selected limestones and fossils. Geochim. Cosmochim. Acta 1964, 28, 1786-1816. [CrossRef]

28. Chen, R. Application of stable oxygen and carbon isotope in the research of carbonate diagenetic environment. Acta Sedimentol. Sin. 1994, 4, 11-21.

29. Luo, B.W.; Wei, G.Q.; Yang, W.; Dong, C.Y. Reconstruction of the late Sinian paleo-ocean environment in Sichuan basin and its geological significance. Geol. China 2013, 40, 1099-1111.

30. Sena, C.M.; John, C.M.; Jourdan, A.L.; Vandeginste, V.; Manning, C. Dolomitization of lower cretaceous peritidal carbonates by modified seawater: Constraints from clumped isotopic paleothermometry, elemental chemistry, and strontium isotopes. $J$. Sediment. Res. 2014, 84, 552-566. [CrossRef]

31. Shackleton, N.J.; Kennett, J.P. Paleotemperature history of the Cenozoic and initiation of Antarctic glaciation: Oxygen and carbon isotope analysis in DSDP sites 277, 279 and 281. In Initial Reports of the Deep Sea Drilling Project; Kennett, J.P., Houtz, R.E., Eds.; U.S. Government Printing Office: Washington, DC, USA, 1975; Volume 29, pp. 743-755.

32. Callen, J.M.; Herrmann, A.D. In situ geochemistry of middle Ordovician dolomites of the upper Mississippi valley. Depos. Rec. 2019, 5, 4-22. [CrossRef]

33. Geochemistry Teaching and Research Section of China University of Geosciences. Geochemistry; Geological Publishing House: Beijing, China, 1979.

34. Chen, X.; Zhao, W.Z.; Zhang, L.P.; Zhao, Z.J.; Liu, Y.H.; Zhang, B.M.; Yang, Y. Discovery and exploration significance of structure-controlled hydrothermal dolostones in the Middle Permian of the central Sichuan Basin. Acta Pet. Sin. 2012, 33, 562-569.

35. Wu, D.; Wu, N.; Gao, J. Paleogeothermal research in Sichuan Basin and its geological significance. Acta Pet. Sin. 1998, 19, $28-334$.

36. Huang, S. A study on carbon and strontium isotopes of late palaeozoic carbonate rocks in the Upper Yangtze platform. Acta Geol. Sin. 1997, 71, 45-53.

37. Han, X.; Bao, Z.; Xie, S. Origin and geochemical characteristies of dolomites in the Middle Permian Formation, SW Sichuan Basin, China. Earth Sci. 2016, 41, 167-176.

38. Veizer, J.; Ala, D.; Azmy, K.; Bruckschen, P.; Buhl, D.; Bruhn, F.; Carden, G.A.F.; Diener, A.; Ebneth, S.; Godderis, Y.; et al. ${ }^{87}$ Sr $/{ }^{86}$ Sr, $\delta^{13} \mathrm{C}$ and $\delta^{18} \mathrm{O}$ evolution of Phanerozoic seawater. Chem. Geol. 1999, 161, 59-88. [CrossRef]

39. Koeshidayatullah, A.; Corlett, H.; Stacey, J.; Swart, P.K.; Boyce, A.; Robertson, H.; Whitaker, F.; Hollis, C. Evaluating new fault-controlled hydrothermal dolomitization models: Insights from the Cambrian Dolomite, Western Canadian Sedimentary Basin. Sedimentology 2020, 67, 2945-2973. [CrossRef]

40. Kareem, K.H.; Al-Aasm, I.S.; Mansurbeg, H. Structurally-controlled hydrothermal fluid flow in an extensional tectonic regime: A case study of Cretaceous Qamchuqa Formation, Zagros Basin, Kurdistan Iraq. Sediment. Geol. 2019, 386, 52-78. [CrossRef]

41. Mansurbeg, H.; Alsuwaidi, M.; Salih, N.; Shahrokhi, S.; Morad, S. Integration of stable isotopes, radiometric dating and microthermometry of saddle dolomite and host dolostones (Cretaceous carbonates, Kurdistan, Iraq): New insights into hydrothermal dolomitization. Mar. Pet. Geol. 2021, 127, 104989. [CrossRef]

42. Beckert, J.; Vandeginste, V.; John, C.M. Relationship between karstification and burial dolomitization in Permian platform carbonates (Lower Khuff-Oman). Sediment. Geol. 2016, 342, 165-179. [CrossRef]

43. He, P.W.; Xu, W.; Zhang, L.J.; Fu, M.Y.; Wu, D.; Deng, H.C.; Xu, H.L.; Sun, Q.M. Characteristics and Genetic Mechanism of Qixia Formation Dolomite in Moxi-Gaoshiti Area, Central Sichuan Basin. Acta Sedimentol. Sin. 2021, 39, 1-18.

44. Gregg, J.M.; Sibley, D.F. Epigenetic dolomitization and the origin of xenotopic dolomite texture. J. Sediment. Petrol. 1984, 54, 908-931.

45. Machel, H.G. Concepts and models of dolomitization: A critical reappraisal. In The Geometry and Petrogenesis of Dolomite Hydrocarbon Reservoirs; Braithwaite, C.J.R., Rizzi, G., Darke, G., Eds.; Geological Society, Special Publications: London, UK, 2004; Volume 235, pp. 7-63.

46. Vahrenkamp, V.C.; Swart, P.K. New distribution coefficient for the incorporation of strontium into dolostone and its implications for the formation of ancient dolostones. Geology 1990, 18, 387-391. [CrossRef]

47. Pinto-Coelho, C.V.; Höfig, D.F.; Fregatto, M.M.; da Silva, T.G.; da Silva, L.G.M.; Ferreira, A.D.; Duarte, J.P.; de Souza, P.C.; Ferreira, M.M.M.; Botelho, A.C.; et al. Hydrothermal dolomitization and porosity development: An example from Precambrian dolomitic rocks of Água Clara Formation, Ribeira Belt, southern Brazil. J. S. Am. Earth Sci. 2019, 94, 102193. [CrossRef]

48. Luo, Y.; Li, G.; Xu, W.; Liu, J.; Cheng, J.; Zhao, J.; Yan, W. The effect of diagenesis on rare earth element geochemistry of the Quaternary carbonates at an isolated coral atoll in the South China Sea. Sediment. Geol. 2021, 420, 105933. [CrossRef]

49. Qing, H.; Bosence, D.W.; Rose, E.P. Dolomitization by penesaline sea water in Early Jurassic peritidal platform carbonates, Gibraltar, western Mediterranean. Sedimentology 2001, 48, 153-163. [CrossRef]

50. Liu, D.; Cai, C.; Hu, Y.; Peng, Y.; Jiang, L. Multistage dolomitization and formation of ultra-deep Lower Cambrian Longwangmiao Formation reservoir in central Sichuan Basin, China. Mar. Pet. Geol. 2021, 123, 104752. [CrossRef] 
51. Zhao, M.J.; Song, Y.; Qin, S.F.; Liu, S.B.; Hong, F.; Fu, G.Y.; Da, J. Geological conditions and oil-gas filling periods of 4 type cenozoic compressional basins in central western China. Chin. J. Geol. 2007, 42, 234-252.

52. Ma, Y.S.; Cai, X.Y.; Zhao, P.R.; Luo, Y.; Zhang, X.F. Distribution and further exploration of the large-medium sized gas fields in Sichuan Basin. Acta Pet. Sin. 2010, 31, 347-354.

53. Honlet, R.; Gasparrini, M.; Muchez, P.; Swennen, R.; John, C.M. A new approach to geobarometry by combining fluid inclusion and clumped isotope thermometry in hydrothermal carbonates. Terra Nova 2018, 30, 199-206. [CrossRef]

54. Mahboubi, A.; Nowrouzi, Z.; Al-Aasm, I.S.; Moussavi-Harami, R.; Mahmudy-Gharaei, M.H. Dolomitization of the Silurian Niur Formation, Tabas block, east central Iran: Fluid flow and dolomite evolution. Mar. Pet. Geol. 2016, 77, 791-805. [CrossRef]

55. Li, T.; Zhu, D.; Yang, M.; Li, P.; Zou, H. Influence of hydrothermal activity on the Maokou Formation dolostone in the central and western Sichuan Basin. Oil Gas Geol. 2021, 42, 639-651.

56. Wang, S.; Cao, Y.; Du, D.; Zhang, Y.; Liu, C. Characteristics and pore genesis of dolomite in Ordovician Yingshan Formation in Gucheng area, Tarim Basin. Acta Petrol. Sin. 2020, 36, 3477-3492.

57. Sun, F.; Hu, W.; Hu, Z.; Liu, Y.; Kang, X.; Zhu, F. Impact of hydrothermal activities on reservoir formation controlled by both faults and sequences boundaries: A case study from the Lower Ordovician in Tahe and Yubei areas, Tarim Basin. Oil Gas Geol. 2020, 41, 558-575.

58. Franchi, F. Petrographic and geochemical characterization of the Lower Transvaal Supergroup stromatolitic dolostones (Kanye Basin, Botswana). Precambrian Res. 2018, 310, 93-113. [CrossRef]

59. Hecht, L.; Freiberger, R.; Gilg, H.A.; Grundmann, G.; Kostitsyn, Y.A. Rare earth element and isotope (C, O, Sr) characteristics of hydrothermal carbonates: Genetic implications for dolomite-hosted talc mineralization at Göpfersgrün (Fichtelgebirge, Germany). Chem. Geol. 1999, 155, 115-130. [CrossRef]

60. Centrella, S.; Beaudoin, N.E.; Derluyn, H.; Motte, G.; Hoareau, G.; Lanari, P.; Piccoli, F.; Pecheyran, C.; Callot, J.P. Micro-scale chemical and physical patterns in an interface of hydrothermal dolomitization reveals the governing transport mechanisms in nature: Case of the Layens anticline, Pyrenees, France. Sedimentology 2020, 68, 834-854. [CrossRef]

61. Wang, Y.; Jin, Y. The formation of dolostone and paleokarst of the Lower Permian series in Sichuan Basin and the relation to the Emei Taphrogenesis. J. Chengdu Univ. Technol. 1997, 24, 8-16.

62. Pan, L.; Hao, Y.; Liang, F. Formation time and tectonic setting of Middle Permian hydrothermal dolomite in southwestern Sichuan Basin. In Proceedings of the Sixteenth National Conference on Palaeogeography and Sedimentology, Xi'an, China, 21 August 2021.

63. Sun, Q.S. A reappraisal of dolostone abundance and occurrence in the Phanerozoic. J. Sediment. Res. 1994, 64, 396-404. [CrossRef]

64. Davies, G.R.; Smith, L.B. Structurally controlled hydrothermal dolostone reservoir facies: An overview. AAPG Bull. 2006, 90, 1641-1690. [CrossRef]

65. Middleton, H.; Pedone, V.; Arne, D. Hydrothermal dolomite distribution in the Emanuel Range as a constraint on timing of fault movement during mineralisation on the Lennard Shelf, Western Australia. ASEG Ext. Abstr. 2019, 2019, 1-6. [CrossRef]

66. Xu, Q.C. Thermal Evolution of Marine Strata in the Central and Western Sichuan Basin; China University of Petroleum: Beijing, China, 2018.

67. Zhi-li, L.U.O. Emei taphrogenesis and natural gas prospecting practices in Sichuan Basin. Xinjiang Pet. Geol. 2009, 30, 419-424.

68. Qi, L.; Gu, Y.; He, P.; Wang, Z.; Jiang, Y.; Li, S.; Zhou, Y. Hydrothermal dolomitization in the Middle Permian in the Central Sichuan Basin, SW China: Evidence from petrology, geochemistry, and fluid inclusions. Arab. J. Geosci. 2021, 14, 115. [CrossRef]

69. Ramkumar, M.; Siddiqui, N.A.; Mathew, M.; Sautter, B.; Hui, P.X.; Nagarajan, R.; Breitfeld, H.T.; Santosh, M.; Menier, D.; Poppelreiter, M. Structural controls on polyphase hydrothermal dolomitization in the Kinta Valley, Malaysia: Paragenesis and regional tectono-magmatism. J. Asian Earth Sci. 2019, 174, 364-380. [CrossRef]

70. Hips, K.; Haas, J.; Győri, O. Hydrothermal dolomitization of basinal deposits controlled by a synsedimentary fault system in Triassic extensional setting, Hungary. Int. J. Earth Sci. 2016, 105, 1215-1231. [CrossRef]

71. Hirani, J.; Bastesen, E.; Boyce, A.; Corlett, H.; Gawthorpe, R.; Hollis, C.; John, C.M.; Robertson, H.; Rotevatn, A.; Whitaker, F. Controls on the formation of stratabound dolostone bodies, Hammam Faraun Fault block, Gulf of Suez. Sedimentology 2018, 65, 1973-2002. [CrossRef] 